\title{
KEDUDUKAN ANAK LUAR KAWIN YANG DIANGKAT OLEH KAKEKNYA DI DESA BATUKAANG KECAMATAN KINTAMANI KABUPATEN BANGLI
}

\author{
Ni Nyoman Oktaviani, Ketut Sukadana, Ni Made Puspasutari Ujianti \\ Fakultas Hukum Universitas Warmadewa, Denpasar - Bali, Indonesia
}

\begin{abstract}
Abstrak
Anak yang lahir luar kawin adalah anak yang dilahirkan dari seorang perempuan yang tidak memikili ikatan perkawinan yang sah dengan laki laki yang sudah menanamkan benih anak di rahimnya. Anak tersebut tidak memiliki kedudukan yang sempurna di mata hukum seperti anak sah pada umumnya. Kelahiran seorang anak merupakan hal yang penting dalam setiap keluarga. Dari sisi kehidupan keluarga anak merupakan keturunan generasi penerus sehingga seorang anak berhak atas kelangsungsan hidup dan identitas dirinya sebagai upaya perlindungan hukum. Permasalahannya adalah bagaimana proses pengangkatan anak luar kawin oleh kakeknya di Desa Batukaang Kecamatan Kintamani Kabupaten Bangli dan bagiamana sistem waris terhadap anak luar kawin yang di angkat oleh kakeknya di Desa Batukaang Kecamatan Kintamani, Kabupaten Bangli? Anak luar kawin tersebut diangkat oleh kakek kandungnya sendiri dan alasan pengangkatan anak luar kawin tersebut karena kakek yang mengangkat tidak memiliki anak laki-laki. Tipe penelitian yang digunakan dalam penelitian ini berupa studi empiris dengan pendekatan yuridis sisiologis. Sumber data bersumber dari data primer dan data sekunder teknik pengumpulan data dilakukan dengan wawancara (interview) dan juga kajian kepustakaan. Prosedur pengangkatan anak ini dilakukan secara adat atau niskala yaitu melakukan upacara pemerasan dimana di buatkan banten secara keagamaaan dan secara hukum dimana anak tersebut dibuatkan akta secara sah sebagaimana anak sah pada umumnya. Setelah proses itu anak tersebut sudah sah menjadi anak dari kakek yang mengangkat baik secara adat dan sistem hukum pewarisan, anak tersebut mewarisi semua warisan dari kakek tersebut.
\end{abstract}

Kata Kunci: Anak; Adat Bali; Hak Waris; Lahir di Luar Kawin; Pengangkatan

\begin{abstract}
Children born out of wedlock are children born to a woman who does not have a legal marriage relationship with a man who has made her give birth to the child. The child does not have a perfect position in the standpoint of the law like a legitimate child in general. The birth of a child is crucial in every family. In terms of family life, children are descendants of the next generation so a child has the right to life and identity as an effort to protect the law. The problem how the adoption of a child born beyond official marriage by his grandfather in Desa Batukaang, the Sub-district of Kintamani, Bangli Regency is executed and what is the inheritance system for such an adopted child in Batukaang Village, Kintamani District, Bangli Regency? The child was appointed by his own grandfather and the reason for the appointment was that the adoptive grandfather did not have a son. The type of research used in this research is an empirical study with a juridical-sociological approach. Types of data are primary data and secondary data, collected through interview and literature review. The procedure for the adoption of the child execution is through customary or noetic way, which is to carry out extortion ceremonies where offerings are religiously and legally made and the child is legally made as a legitimate child in general. Ultimately, the child is legitimate to be the child of the adopting grandfather both in a customary and inheritance legal system, the child inherits all inheritance from the grandfather.
\end{abstract}

Keywords: Child; Balinese customs; Inheritance Rights; Born outside of marriage; Appointment

\section{PENDAHULUAN}

Anak merupakan anugerah yang di berikan Tuhan Yang Maha Esa yang senantiasa wajib dirawat dan dijaga. Pada segi kehidupan berkeluarga anak adalah keturunan atau generasi penerus sehingg a setiap anak berhak atas kelangsungan hidup dan identitas dirinya sebagai upaya perlindungan hukum.bisa di lakukan dengan cara memberikan identitas diri anak sejak lahir (Jamaludin \& Amalia, 2016:2). 
Lahirnya seorang anak ke dunia adalah peristiwa yang penting dan berharga bagi setiap keluarga. Bayi yang baru lahir harus segera dilaporkan kekantor catatan sipil agar tercatat status kependudukannya sekalipun bayi itu lahir tanpa seorang ayah (anak di luar nikah) karena status kependudukan itu sangat penting bagi kehidupannya nanti. Seorang anak yang dilahirkan di luar perkawinan tidak mempunyai ikatan kekeluargaan menurut hukum dengan yang menikahinya maka seorang anak tersebut mewarisi dari ibunya dan keluarga ibunya. Menurut hukum Islam, seorang anak yang lahir di luar perkawinan tidak bisa diakui ataupun dipisahkan oleh ayahnya. Anak itu hanya mempunyai hubungan hukum dengan ibunya. Tetapi anak tersebut tetap mempunyai seorang ibu yaitu perempuan yang melahirkannya ke dunia dengan pengertian antara seorang anak dan ibu itu ada hubungan hukum. Sama halnya dengan seorang anak yang sah yang memiliki seorang ayah (Poespasari, 2006: Surya \& Hajati, 2016).

Menurut Hukum Perdata, seorang anak yang terlahir di luar perkawinan menurut istilah hukum perdata dinamakan anak a lam. Seorang anak yang lahir di luar perkawinan bisa diakui oleh ayah atau ibunya. Menurut suatu sistem yang telah diterapkanpada kitab BW (KUH Perdata) adanya keturunan atau yang dapat disebutsebagai kelahiran dari seorang anak di luar perkawinan itu belum terjadi hubungan keluarga di antara anak dengan orangtuanya sebelum terbitnya pengakuan dari suatu hubungan keluarga dengan segala resiko nya terutama pada hak ahli waris antara anak tersebut dengan orang tua yang telah mengakuinya. Jadi seorang anak yang terlahir di luar perkawinan itu statusnya adalah anak yang sah (Kuncoro, 2015: 94).

Syarat seorang anak yang terlahir di luar perkawinan agar dapat menerima warisan yaitu dengan cara orang tua kandungnya harus mengakui dengan sah seorang anak tersebut sebagai anaknya. Pada KUHPerdata tertera disana prinsip bahwa hanya orang yang memiliki hubungan hukum de ngan pewaris yang berhak menerima warisan. Seorang anak yang terlahir di luar perkawinan dinyatakan memiliki hubungan hukum jika dayah ibunya sudah member i pengakuan yang sah. Hubungan hukum itu sifatnya terbatas yang artinya hubungan hukum tersebut hanya terjadi di antara seorang anak yang terlahir di luar perkawinan dan diakui oleh ayah dan ibunya yang mengakuinya saja [Pasal 873 KUHPerdata]. Seorang anak di luar perkawinan bisa menerima warisan hanya jika mempunya hubungan hukum dengan pe waris. Hubungan hukum tersebut ada jika orang tua dari anak tersebut membuat pengakuan.

Kajian tentang hak waris yang terkait dengan anak sudah banyak muncul dalam penelitianpenelitian bahkan dalam dua dekade terakhir, seperti penelitian yang dilakukan oleh Purwanto (2008); Hendrako (2017); Loho (2017); Deviyanti \& Salain (2017); dan Hulzannah dkk. (2020). Namun, terkait pengaturan hukum tentang kedudukan dan hak waris anak yang lahir di luar pernikahan tetapi diadopsi oleh kakeknya belum pernah dikaji, khususnya di daerah Bali. Oleh Karena iut, penelitian ini mengkaji bagaimana proses pengangkatan anak luar kawin oleh kakeknya di Desa Batukaang Kecamatan Kintamani Kabupaten Bangli dan bagiamana sistem waris terhadap anak bersama kakeknya tersebut.

\section{METODE PENELITIAN}

Pada penulisan ini, model penelitian yang dipakai yaitu penelitian yang berupa studi empiris agar ditemukannya teori-teori yang menyangkut proses terjadinya dan proses berjalannya hukum di lingkungan masyarakat. Dalam istilah lain yaitu penelitian yang dilaksanakan karena terjadi keadaan sebenarnya atau keadaan nyata terjadi di lingkungan masyarakat dengan tujuan agar mendapatkan pengetahuan dan mengetahui fakta fakta serta data yang diperlukan dapat terkumpul. Kemudian terkait pada identifikasi masalah yang pada nantinya akan menuju pada penyelesaian masalah. Pada penelitian ini, pendekatan masalah yang digunakan adalah pendekatan yuridis sosiologis yaitu suatu pendekatan penelitian yang berdasar kepada salah satu ketentuan hukum atau peraturan yang diterapkan dan berlaku pada suatu kejadian yang terjadi di lapangan dan dalam praktiknya sesuai dengan yang dialami di lingkungan masyarakat. Setelah data terkumpul, dianalisis dengan analisis kualitatif yakni diuraikan secara deskriptif dan disajikan secara informal, menggunakan kata-kata. 


\section{HASIL PENELITIAN DAN PEMBAHASAN \\ Proses Pengangkatan Anak yang Lahir di Luar Kawin oleh Kakeknya di Desa Batukaang Kecamatan Kintamani Kabupaten Bangli dan Sistem Waris terhadapnya}

Pengertian dari anak yang terlahir di luar perkawinan yaitu hubungan antara seorang pria dan wanita yang dapat membuat keturunan sedangkan hubungan antara keduanya bukan dalam ikatan perkawinan yang sah menurut hukum positif dan peraturan agama yang dianutnya. Dalam Kitab Undang Undang Hukum Perdata terteraAnak yang terlahir di luar perkawinan yaitu anak yang terlahir dari hubungan antara seorang laki laki dan seorang perempuan di luar perkawinan yang sah menurut hukum. Predikat sebagai anak yang terlahirdi luar nikah tentu akan terus melekat pada anak yang dilahirkan di luar perkawinan tersebut. Tertera pada KUHP bahwa pengertian anak yang terlahirdi luar nikah dikategorikan menjadi 2 macam yakni dalam arti luas dan dalam arti sempit (Hartanto, 2015: 79).

Seorang anak yang terlahir di luar perkawinan bisa diakui sebagai anak yang dilahirkan oleh seorang ibu walaupun pria yang berada dalam ikatan perkawinan yang sah dengan ibunya tersebut bukan merupakan ayah kandungnya. Meski begitu, anak tersebut bukan dikategorikan pada kelompok anak zina atau anak sumbang. Seorang anak yang terlahirdi luar perkawinan dalam arti luas meliputi anak zina atau anak sumbang atau anak luar kawin yang lainnya (Sastroatmodjo \& Aulia, 1978: 58). Seorang anak yang terlahir setelah anak yang sebelumnya meninggal atau bercerai belum tentu disebut sebgai anak luar kawin karena jika anak itu dibenihkan selama ibu yang mengandungnya terikat pada perkawinan yang sah dan di lahirkan dalam jangka waktu 300 hari sesudah perceraian dari perkawinan yang sah [Pasal 255 KUH Perdata]. Seorang anak di luar perkawinan yang dimaksud merupakan anak di luar kawin selain anak sumbang dan anak zina. Dalam arti sempit, anak di luar perkawinan yaitu berarti bukan termasuk dalam kategori anak zina. Jadi anak yang terlahir di luar kawin dalam arti sempit ini dapat memiliki hubungan dengan pewaris jika pewaris mengakui anak luar kawin tersebut.

Pengakuan anak yang dimaksud di sini bukan pengakuan secara diam-diam akan tetapi pengakuan yang dilakukan di pencatatan sipil dengan catatan akta kelahiran anak tersebut atau dengan akta perkawinan orang tua dari anak tersebut atau dengan surat akta tersendiri dari pegawai pencatatan sipil dan diperbolehkan juga dengan akta notaris. Ini berarti tersebut mempunyai ikatan hubungan kekeluargaan dengan segala risiko-risikonya terutama dengan hak mewaris jadi mirip dengan status ikatan kekeluargaan dengan anak sahnya perbedaannya hanya seora ng anak di luar perkawinan tersebut tidak ada ikatannya dengan ay ahnya sebagai yang membangkitkannya. Lain halnya jika anak yang memiliki ikatan hubungan perdata dengan ibunya dan keluarga ibunya juga memiliki hubungan perdata dengan ayah dan keluarga ayahnya.

Berdasarkan aturan hukum, seorang anak yang dilahirkan di luar perkawinan tidak memiliki ikatan keluarga yang sahdengan yang menikahinya jadi dapat disimpulkan bahwa anak tersebut mewarisi dari seorang ibu dan keluarga ibunya (Afandi, 1984). Status seorang anak di luar kawin bisa jadi sebuah masalah yang cukup besar bagi seorang ibu yang melahirkan orangtua dari perempuan yang melahirkan seorang anak di luar perkawinan atau tanpa perkawinan yang sah. Seorang ibu tersebut juga nantinya akan merasa malu karena perbuatan seorang anak perempuannya di lingkungan masyarakat setempat sehingga melahirkan anak di luar kawin tersebut. Selain itu, seorang anak tersebut juga bisa diejek dan dikucilkan dengan teman-temannya di pergaulannya. Jadi, dengan terlahirnya seorang anak di luar perkawinan dapat menciptakan banyak pertikaian dalam keluarga dan pada masyarakat menyangkut status kedudukan hak dan kewajiban seorang anak tersebut (Abdurahman \& Syahrini, 1987: 234).

Menurut Pasal 43 UU Nomor 1 Tahun 1974 dimana tertera tentang pernikahan seorang anak yang dilahirkan di luar perkawinan hanya memiliki hubungan perdata dengan ibunya dan keluarga ibunya dan dengan laki laki sebagai ayahnya yakni yang berstatus sah dalam perkawinan dengan ibu dari anak tersebut, yang bisa dibuktikan dengan ilmu pengetahuan dan teknologi atau adanya alat bukti lain berdasarkan hukum memiliki ikatan atau hubungan darah dikategorikan sebagai hubungan perdata deng an keluarga ayahnya.

Oleh sebab itu jika seorang ibu ingin anaknya mem iliki hubungan perdata dengan ayahnya, ada 3 cara yang dapat dilakukan, yakni:

1. Sang ayah harus membuat pengakuan yang sah secara hukum dengan persetujuan ibu dari anak tersebut untuk anaknya yang dilahirkan di luar ikatan pernikahan yang sah. 
2. Membuktikannya dengan ilmu pengetahuan dan teknologi atau tes DNA. Hal ini jika ayah dan ibu dari seorang anak tersebut tidak memiliki hubungan perkawinan yang sah baik secara hukum ataupun agama. Tes DNA dilakukan jika ingin anak tersebut memiliki ikatan hubungan perdata dengan ayahnya atau keluarga ayahnya.

3. Pengesahan dalam statushukum yakni pengesahan terhadap anak yang dilahirkan di luar perkawinan yang sah menjadi anak sah dari sepasang suami dan istri.

Pada suatu kasus yang terjadi di Desa Baatukaang Kecamatan Kintamani Kabupaten Bangli, penulis memberikan hasil wawancara yang menyangkut tentang mengapa alasan mengangkat anak di luar perkawinan. Hal itu terjadi karena keluarga yang mengangkat anak tersebut tidak dapat mempunyai keturunan anak laki-laki yang akan meneruskan warisan dan meneruskan hak dan kewajiban di dalam masyarakat.

Alasan lain mengapa mengangkat anak di luar per kawinan itu agar terhindar dari aib dalam keluarga karena anak yang diangkatnya terlahir dari keluarganya sendiri, sehingga sang kakek mengangkat anak tersebut sebagai anaknya (Wawancara dengan I Putu Buda pada tanggal 25 Januari 2020).

Dengan adanya kasus yang terjadi di Desa Batukaang Kecamatan Kintamani Kabupaten Bangli tersebut dapat dijelaskan bahwa prosedur dari pengangkatan anak di luar perkawinan yaitu pertama dari pihak keluarga yang hendak mengangkat anak harus meminta izin persetujuan dari keluarga yang pada kasus ini yang hendak mengangkat anak ialah kakek kandungnya sendiri sehingga dari pihak keluarga tentusetuju. Jika sudah disepakati persetujuan tersebut, seorang anak yang hendak diangkat juga harus dimintai persetujuan jika anak ini dewasa. Setelah semua itu, wajib diberitahukan kepada prajuru adat daerah setempat. Jika tidak terjadi permasalahan dalam peng angkatan anak tersebut, langkah berikutnya yaitu mengadakan upacara Pemerasan pada anak yang diangkat tersebut. Proses upacara pemerasan ini dengan dibuatkannya banten (sesaji) pada upacara keagamaan ini yakni anak yang diangkat menarik benang dari banten hingga benangnyaterputus. Upacara ini dipimpin oleh seorang pemangku dan disaksikan oleh keluarga yang bersangkutan.

Setelah dilakukannya pengangkatan anak dan pengadaan upacara keagamaan tersebut, maka telah sah secara hukum adat atau awig-awig di desa Batukaang. Setelah itu akan diumukan kepada masyarakat sekitar di pesangkepan bahwa telah terjadi pengangkatan anak dan pengadaan upacara Pemerasan yang berarti anak tersebut sudah sah secara adat menjadi anak dari orang tua yang mengangkatnya. Nantinya ti dak berstatus sebagai anak di luar perkawinan lagi (Wawancara dengan Bendesa Adat Batukaang pada tanggal 10 Maret 2020) Secara administratif juga anak yang diangkat tersebut sudah sah statusnya sebagai anak dari orang tua angkatnya yakni kakek kandungnya sendiri yang tertera di kartu keluarga (Wawancara dengan Kepala Desa Batukaang pada tanggal 1 Januari 2020). Faktor yang paling penting dalam pembagian harta warisan terhadap anak angkat tersebut yaitu pertama mengenai pernikahan sebab berkaitan terhadap ikatan hubungan kekerabatan yang dimana adanya larangan pernikahan atau menjadi pasangan suami istri yang sah. Kedua, mengenai pembagian warisan atau harta yang ditinggalkan yakni harus memiliki ikatan keluarga. Pada pembagian warisan, antara anak angkat $d$ engan anak kandung berdasarkan pada asas parimirna dengan dasar welas asih dan kesukarelaan sehingga anak angkat dan keluarga dari ibu anak itu tidak mempunyai hak untuk menuntut harta warisan dari bapak biologinsnya. Berdasarkan hukum adat yang berlaku, besarnya pemberian warisan tidak menggunakan kalkulasi tertentu atau tidak ada hitungan yang mengatur melainkan hanya berdasar kerelaan atau keikhlasan dari keluarga bapak biologisnya atau dapat berupa surat wasiat yang berisi apa saja yang ingin diwarisi oleh bapak biologisnya itu.

Jadi secara hukum adat yang diterapkan di Desa Batukaang tersebut, anak itu telah sah menjadi anak angkat dari kakeknya sendiri. Sehingga apabila anaik itu dewasa nanti, anak tersebut harus menggantikan hak dan kewajiban secara adat kakeknya atau orang tua angkatnya seperti ayah-ayahan dipura atau didesa (wawancara dengan Bendesa Adat Batukaang pada tanggal 17 Maret 2020).

\section{SIMPULAN DAN SARAN}

1. Simpulan

Proses diangkatnya seorang anak yang terlahir di luar perkawinan oleh kakeknya sendiri di Desa Batukaang Kecamatan Kintamani Kabupaten Bangli. Pihak keluarga yang hendak mengangkat anak harus meminta persetujuan dari keluarga. Apabila disetujui dan disepakati, keluarga tersebut harus meminta persetujuan dari anak yang hendak diangkatnya sebagai anak. Hal ini berlaku apabila anak 
yang hendak diangkat telah dewasa.Selanjutnya harusmelaporkan kepada prajuru adat setempatdan mengadakan upacara keagamaan yakni melaksanakan upacara pemerasan. Kemudiandiberitahukan atau diumumkan kepada masyarakat setempat melalui sangkepan bahwa anak tersebut telah diangkat dan secara administrasi anak tersebut masuk ke dalam kartu keluarga orang tua yang mengangkatnya yakni kakeknya sendiri. Pada sistem pembagian harta warisan atas anak yang terlahir di luar perkawinan yang sudah diangkat oleh kakeknya di Desa Batukaang Kecamatan Kintamani Kabupaten Bangli anak tersebut berhak menerima warisan dari keluarga yang mengangkatnya tersebut.

\section{Saran}

Kepada seluruh masyaraka terkhusus kepada orang tua agar tetap menjaga, merawat, memberi perhatian serta pengawasan dan memberikan pendidikan yang baik untuk anak-anaknya khususnya untuk anak perempuan agar berhati-hati dalam pergaulannya karena pada jaman sekarang jika sedikit saja salah pergaulan dapat merusak masa depan dari anak tersebut.Agar tidak menciptakan hal-hal yang tidak diinginkan seperti hamil di luar nikah sehinggamenyebabkan kelahiran anak di luar adanya pernikahan yang sah. Bagi pemerintah disarankan untuk mengadakan sosialisasi untuk anak muda mengenai seberapa pentingnya pendidikan. Sehingga dengan pengetahuan ini anak muda dapat lebih berhati-hati dalam pergaulannya dan menghindari pergaulan bebas agar nantinya tidak ada lagi kasuskasus anak yang terlahir di luar perkawinan tersebut.

\section{DAFTAR PUSTAKA}

Abdurahman, \& Syahrini. (1987). Masalah Perkawinan di Indonesia (5th ed.). Alumni.

Afandi, A. (1984). Hukum Waris, Hukum Keluarga, Hukum Pembuktian. Bina Aksara.

Deviyanti, P. A. S., \& Salain, M. S. P. D. (2017). Hak Anak Tiri terhadap Waris dan Hibah Orang Tua Ditinjau dari Hukum Waris Islam. Kertha Semaya, 5(2), 1-5.

Hartanto, J. A. (2015). Hukum Waris Kedudukan dan Hak Waris Anak Luar Kawin menurut Burgerlijk Wetboek Pasca Putusan Mahkamah Konstitusi. Laks Bang.

Hendrako, E. (2017). Hak Waris Anak Perempuan terhadap Harta Peninggalan (Studi Putusan MA RI No. 4766/Pdt/1998). Lex Privatum, 3(1), 139-146.

Hulzannah, M., Riduansyah, Putra, J. R., Riski, R. A., \& Pohan, I. (2020). Pembagian Hak Ahli Waris pada Anak Angkat di Kabupaten Labuhanbatu Ditinjau dari Perspektif Hukum Islam. Jurnal Ilmiah Advokasi, 08(01), 19-28.

Jamaludin, \& Amalia. (2016). Buku Ajar Hukum Perkawinan (Sulawesi). Unimal Press.

Kuncoro, W. (2015). Waris: Permasalahan dan Solusinya. Raih Asa Sukses.

Loho, S. (2017). Hak Waris Anak di Luar Perkawinan Sah Berdasarkan Putusan Mahkamah Konstitusi Nomor 46/PUU-VIII-2010. Lex Crimen, 4(3), 169-176.

Poespasari, E. D. (2006). Hak Waris Anak dalam Sistem Hukum Adat Masyarakat Osing Banyuwang. Perspektif Hukum, 6(2), 114-129.

Purwanto. (2008). Analisis Hak Mewaris Anak Yang Lahir Dari Perkawinan Beda Agama [Universitas Diponegoro]. In Al-Ishlah: Jurnal Ilmiah Hukum.

Sastroatmodjo, A., \& Aulia, W. (1978). Hukum Perkawinan di Indonesia (2nd ed.). Bulan Bintang.

Surya, I. K., \& Hajati, S. (2016). Hak Waris Sentana Mulih Daha (Pulang Kembali) Akibat Perceraian Menurut Hukum Adat Bali. Universitas Erlangga. 